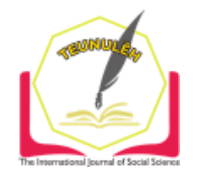

Jurnal Ilmiah Teunuleh

The International Journal of Social Sciences

Vol. 1, Issue. 2, Dec 2020

E-ISSN: 2746-4393

\title{
ANALYSIS OF TEACHER ABILITIES IN IMPLEMENTING ONLINE LEARNING IN ELEMENTARY SCHOOLS OF THE NORTH SUMATRA PAB FOUNDATION
}

\author{
Yusrizal $^{1}$ \\ Fatmawati $^{2}$ \\ ${ }^{12}$ Sekolah Tinggi Keguruan dan IImu Pendidikan Amal Bakti \\ ${ }^{1}$ yusrizaldns@gmail.com \\ 2fatmecincau22@gmail.com
}

\begin{abstract}
This study aims to describe the ability of teachers to implement online learning in private primary schools in North Sumatra PAB. The method used in this research is a quantitative method with a descriptive research type. Descriptive research in this study aims to describe the observed data. The population in this study were 31 schools in North Sumatra PAB private primary schools. The sampling technique in this study was random sampling, while the sample in this study was 9 schools with each school being taken by one teacher as the research sample. The data collection technique in this research is observation. The data analysis technique is using the descriptive data analysis technique. Based on the results of the study, it can be concluded that: the teacher's ability to implement online learning in North Sumatra PAB primary schools is low. The low ability of teachers is caused by several factors, but in this study the biggest factor is the lack of teacher motivation in learning technology, which causes online learning not to be carried out as expected. Therefore, the government's attention to the mastery of technology for all teachers is something that needs to be improved considering that one of the biggest indicators of the times is the rapid development of technology.
\end{abstract}

Keywords: Teacher Ability, Online Learning, The Covid-19 Pandemic

\section{A. Introduction}

Since January 30, 2020 the Covid-19 virus has been designated by WHO as a pandemic (Sohrabi, et al., 2020). Since then there have also been many changes in human work activities, one of the most felt sectors is in the education sector, for 
example, such as the closure of several schools in areas affected by the Covid-19 virus. UNESCO noted that there were 63 million teachers affected by Covid-19, and 1.3 billion students worldwide were closed (Joshi, Vinay, \& Bhaskar, 2020). As a quick step taken by the Indonesian government in breaking the chain of the Covid-19 virus, namely by issuing a Ministry of Education and Culture circular by changing the learning patterns that are usually carried out face-to-face in schools into distance learning (Lindawati \& Rahman, 2020) (Yusrizal, Lubis, Fatmawati, \& Muzdalifah, 2020). Distance learning is learning that has been carried out by teachers interactively through video conferencing (Muhammad, 2020).

Distance learning or commonly referred to as online learning is a way to solve educational problems regarding the implementation of learning. The definition of online learning is a learning method with an interactive model based on the Internet and Learning Management System (LMS), for example using Zoom Meeting, Geogle Meet, Google Classrom, Google Duo, Edmodo, to the Whatsapp Group (Enriquez, 2014; Sicat, 2015; Iftakhar, 2016). Online activities include webinars, online classes, and all activities are carried out using the internet and computer networks (Hasibuan et al., 2019).

After the Ministry of Education and Culture establishes and converts learning into distance learning, since then teachers have felt confused in designing appropriate and effective learning to use during distance learning. This is in line with the opinion of (Yusrizal, Lubis, Fatmawati, \& Muzdalifah, 2020) which states that distance learning is a learning pattern that is considered new in Indonesia so that it is very difficult for teachers to adjust to managing learning during the pandemic era. The biggest cause of the difficulty of teachers in adjusting themselves is the low competence of teachers in using technology so that distance learning is deemed not implemented properly. In addition, the internet network cannot be reached by all student residence locations (Yusrizal, Lubis, Fatmawati, \& Muzdalifah, 2020).

Long before the pandemic, the government had long made efforts to create professional teachers. The most emphasized thing to improve is the mastery of technology, because the main indicator of the progress of the times is the increasingly rapid development of technology. However, since the emergence of the Covid-19 outbreak, this problem has become very urgent to be resolved, considering that online learning requires teachers to be able and proficient in using technology. In fact, until now there are still many teachers who are unable to use it so that the implementation 
Analysis of Teacher Abilitiesin Emplementing Online Learning...

of online learning as recommended by the Ministry of Education and Culture is deemed not implemented properly.

Apart from these problems, there are other problems that are no less important and should be of concern to the government, namely the lack of supporting facilities for distance learning, many students do not have smartphones, making it difficult for teachers to carry out learning (Yusrizal, Lubis, Fatmawati, \& Muzdalifah, 2020). In addition, the problems that occur are not only in the facilities, but the availability of internet quota which is quite expensive for teachers and students is also an important issue that must be considered (Elfahmi, 2020). This problem has been resolved a little with the help of a learning quota from the government which is still running, but the target is not evenly distributed among all teachers and students who need it. However, the biggest problem lies not in the limited quota but on the internet network that cannot be reached evenly. This is in line with the opinion of Hartanto (2016) which states that internet coverage is one of the obstacles faced by teachers and students whose homes are difficult to access the internet, especially since these students live in rural, remote and disadvantaged areas.

This fact forces teachers to be more creative in managing learning so that learning objectives during the pandemic can still be achieved. Teachers must ensure teaching and learning activities continue, even though students are at home (Elfahmi, 2020). Because teachers are always responsible for improving student learning outcomes, steps that can be taken in order to improve student learning outcomes are by creating active teaching and learning activities (Yusrizal, Hajar, \& Tanjung, 2019). Therefore, the quality of teachers in teaching, both directly and indirectly, can affect the quality of learning (Malyana, 2020).

Distance learning is a solution that is considered effective in breaking the chain of spreading Covid-19 in schools. Good cooperation between teachers, students, parents of students and the school is a determining factor for online learning to be carried out well. For this reason, this study aims to analyze the ability of teachers to carry out distance learning in the era of the Covid-19 pandemic.

\section{B. Method}

This research uses quantitative methods with descriptive research type. This study aims to analyze the ability of elementary school teachers under the auspices of the $P A B$ foundation in implementing online learning. Online learning that is meant in 
this research is learning that is carried out by the teacher using the zoom meeting application, google classroom, and WhatsApp. The population of this study were 31 high-grade teachers in elementary schools under the auspices of the PAB foundation. While the sample in this study were 9 schools with 3 high class teachers in each school, totaling 27 teachers. Data collection techniques using observation. The data analysis technique is to describe the distribution of data needed for drawing conclusions.

\section{Finding and Discussion}

\section{Finding}

a. Teacher Ability to Use Zoom Meeting

Based on the results of data collection through a questionnaire, it can be described that the ability of North Sumatra PAB primary school teachers to use zoom meetings is as follows:

Table 1 Scores of Teachers' Ability to Apply Zoom Meeting

\begin{tabular}{|c|l|c|c|c|c|c|c|c|c|c|}
\hline \multirow{2}{*}{} & \multirow{2}{*}{ Indicator } & \multicolumn{7}{|c|}{ School } \\
\cline { 3 - 9 } & & 1 & 2 & 3 & 4 & 5 & 6 & 7 & 8 & 9 \\
\hline 1 & Download applications from android & 2 & 1 & 3 & 3 & 3 & 2 & 1 & 1 & 3 \\
\hline 2 & Download applications from the PC & 1 & 2 & 3 & 1 & 1 & 1 & 3 & 3 & 2 \\
\hline 3 & Open the application & 1 & 1 & 2 & 3 & 2 & 1 & 1 & 1 & 2 \\
\hline 4 & Create an account & 1 & 1 & 1 & 1 & 2 & 1 & 3 & 1 & 1 \\
\hline 5 & Change the account name & 1 & 1 & 2 & 3 & 3 & 1 & 1 & 1 & 1 \\
\hline 6 & Change account photo & 1 & 1 & 2 & 1 & 1 & 1 & 2 & 1 & 1 \\
\hline 7 & Create virtual classes & 2 & 1 & 2 & 2 & 2 & 1 & 2 & 1 & 2 \\
\hline 8 & $\begin{array}{l}\text { Create virtual classes according to the } \\
\text { specified hours }\end{array}$ & 2 & 1 & 2 & 3 & 1 & 1 & 1 & 3 & 1 \\
\hline 9 & $\begin{array}{l}\text { Carry out learning in classes that have } \\
\text { been made }\end{array}$ & 3 & 1 & 2 & 2 & 1 & 1 & 1 & 1 & 2 \\
\hline 10 & Activate sound and video & 3 & 1 & 1 & 3 & 1 & 1 & 1 & 2 & 1 \\
\hline 11 & Ability to open the share screen & 1 & 1 & 1 & 2 & 2 & 1 & 2 & 1 & 1 \\
\hline 12 & Ability to close the share screen & 1 & 1 & 1 & 1 & 2 & 1 & 3 & 2 & 1 \\
\hline 13 & Class management skills & 1 & 1 & 1 & 3 & 3 & 1 & 2 & 3 & 2 \\
\hline 14 & Ability to end virtual classes & 2 & 1 & 2 & 1 & 2 & 1 & 1 & 1 & 1 \\
\hline & & 22 & 15 & 25 & 29 & 26 & 15 & 24 & 22 & 21 \\
\hline & Total Score & & & 22.11 & & \\
\hline
\end{tabular}


Analysis of Teacher Abilitiesin Emplementing Online Learning...

The decision-making criteria for the teacher's ability to use Zoom Meeting can be described as follows:

$\begin{aligned} \text { Indicator } & =14 & \text { SD } & =\text { Range } / 6 \\ \text { Range } & =X_{\text {maks }}-X_{\min } & & =28 / 6=4,7 \\ & & & \\ \text { Mean } & & & \\ & & & \\ & =(42+14=28 & & \\ \text { maks } & \left.+X_{\min }\right) / 2 & & \end{aligned}$

Table 2 Categories of Teacher Ability to Apply Zoom Meeting

\begin{tabular}{|c|c|}
\hline Category & Score Range \\
\hline Low & $\mathrm{X}<\mathrm{M}-1 \mathrm{SD} \mid \mathrm{X}<23,3$ \\
\hline Medium & $\mathrm{M}-1 \mathrm{SD} \leq \mathrm{X}<\mathrm{M}+1 \mathrm{SD} \mid 23,3 \leq \mathrm{X}<32,7$ \\
\hline High & $\mathrm{M}+1 \mathrm{SD} \leq \mathrm{X} \mid 32,7 \leq \mathrm{X}$ \\
\hline
\end{tabular}

Based on table 1 , it is found that the average score of the teacher's ability to apply the Zoom Meeting is 22.11. Thus it can be concluded that the teacher's ability to apply Zoom Meeting is in the low category.

b. Teacher Ability to Use Google Classroom

Based on the results of data collection through questionnaires, it can be described that the ability of North Sumatra PAB primary school teachers to use Google Classroom is as follows:

Table 3 Scores of Teachers' Ability to Apply Google Classroom

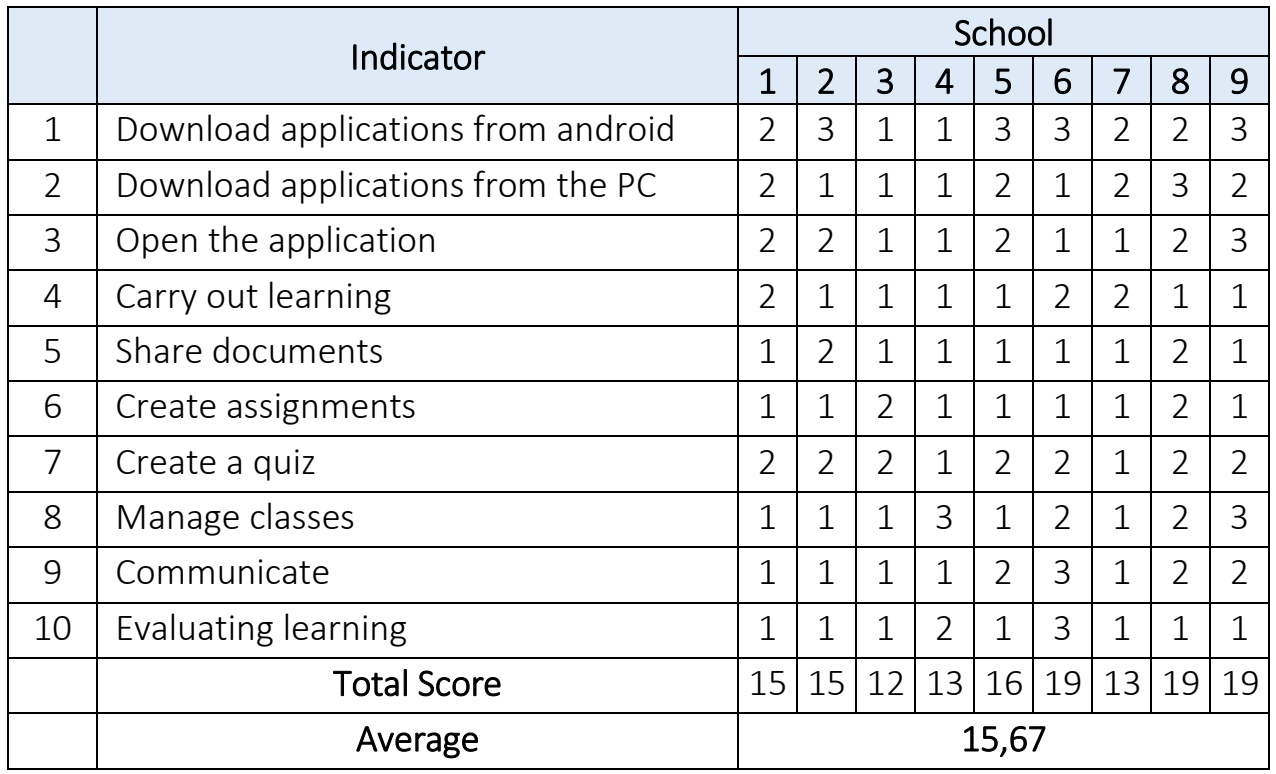




\section{Yusrizal, Fatmawati}

The decision-making criteria for the teacher's ability to apply Google Classroom can be described as follows:

$$
\begin{array}{rlrl}
\text { Indicator } & =10 & \text { SD } & =\text { Range } / 6 \\
\text { Range } & =X_{\text {maks }}-X_{\min } & & =20 / 6=3,3 \\
& & 30-10=20 & \\
\text { Mean } & =\left(X_{\text {maks }}+X_{\min }\right) / 2 & \\
& =(30+10) / 2=20 &
\end{array}
$$

Table 4 Teacher Ability Category Applying Google Classroom

\begin{tabular}{|c|c|}
\hline Category & Score Range \\
\hline Low & $\mathrm{X}<\mathrm{M}-1 \mathrm{SD} \mid \mathrm{X}<16,7$ \\
\hline Medium & $\mathrm{M}-1 \mathrm{SD} \leq \mathrm{X}<\mathrm{M}+1 \mathrm{SD} \mid 16,7 \leq \mathrm{X}<23,3$ \\
\hline High & $\mathrm{M}+1 \mathrm{SD} \leq \mathrm{X} \mid 23,3 \leq \mathrm{X}$ \\
\hline
\end{tabular}

Based on table 3, it is found that the average score of the teacher's ability to apply Google Classroom is 15.67 . Thus it can be concluded that the ability of teachers to apply Google Classrom is in the low category.

\section{Ability to Use WhatsApp}

Based on the results of data collection through questionnaires, it can be described that the ability of North Sumatra PAB elementary school teachers to use WhatsApp as a support for online learning is as follows:

Table 5 Score Teacher Ability to Apply WhatsApp

\begin{tabular}{|c|l|c|c|c|c|c|c|c|c|c|}
\hline \multirow{2}{*}{ Indicator } & \multicolumn{10}{|c|}{ School } \\
\cline { 3 - 10 } & & 1 & 2 & 3 & 4 & 5 & 6 & 7 & 8 & 9 \\
\hline 1 & Download applications from android & 3 & 2 & 3 & 3 & 3 & 3 & 2 & 3 & 3 \\
\hline 2 & Open WhatsApp Web & 2 & 2 & 2 & 2 & 2 & 3 & 2 & 3 & 2 \\
\hline 3 & Create class groups & 1 & 2 & 1 & 3 & 2 & 3 & 1 & 2 & 3 \\
\hline 4 & Communicate in class groups & 2 & 1 & 2 & 3 & 3 & 2 & 2 & 3 & 1 \\
\hline 5 & Manage classes & 3 & 2 & 3 & 3 & 3 & 3 & 1 & 2 & 3 \\
\hline 6 & Send photos, videos and documents & 3 & 3 & 2 & 3 & 1 & 3 & 3 & 2 & 1 \\
\hline 7 & Create Voice Notes & 2 & 2 & 2 & 3 & 2 & 2 & 2 & 3 & 2 \\
\hline 8 & Save student contacts & 2 & 3 & 3 & 3 & 3 & 2 & 1 & 2 & 3 \\
\hline 9 & Download files & 3 & 1 & 3 & 3 & 2 & 3 & 2 & 2 & 2 \\
\hline 10 & Evaluate & 3 & 3 & 3 & 2 & 2 & 3 & 3 & 3 & 3 \\
\hline & Total Score & 24 & 21 & 24 & 28 & 23 & 27 & 19 & 25 & 23 \\
\hline & Average & \multicolumn{7}{|c|}{23,78} \\
\hline
\end{tabular}


Analysis of Teacher Abilitiesin Emplementing Online Learning...

The decision-making criteria for the teacher's ability to apply WhatsApp as a support for online learning can be described as follows:

$$
\begin{aligned}
& \text { Indicator }=10 \\
& \text { Range } \quad=X_{\text {maks }}-X_{\text {min }} \\
& \text { SD }=\text { Range } / 6 \\
& =30-10=20 \\
& \text { Mean } \quad=\left(X_{\text {maks }}+X_{\min }\right) / 2 \\
& =(30+10) / 2=20
\end{aligned}
$$

Table 6 Teacher Ability Category to Apply WhatsApp

\begin{tabular}{|c|c|}
\hline Category & Score Range \\
\hline Low & $\mathrm{X}<\mathrm{M}-1 \mathrm{SD} \mid \mathrm{X}<16,7$ \\
\hline Medium & $\mathrm{M}-1 \mathrm{SD} \leq \mathrm{X}<\mathrm{M}+1 \mathrm{SD} \mid 16,7 \leq \mathrm{X}<23,3$ \\
\hline High & $\mathrm{M}+1 \mathrm{SD} \leq \mathrm{X} \mid 23,3 \leq \mathrm{X}$ \\
\hline
\end{tabular}

Based on table 5, it is found that the average score of the teacher's ability to apply WhatsApp is 23.78. Thus it can be concluded that the teacher's ability to apply WhatsApp is in the high category.

More clearly about the percentage of teacher ability in implementing online learning is presented visually as follows:

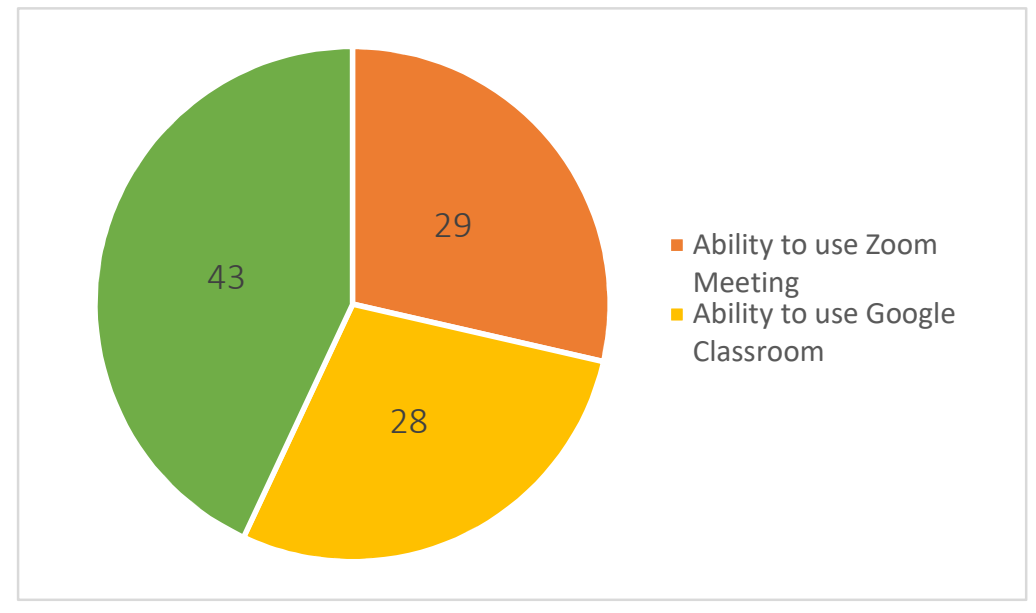

Figure 1 Teacher Ability to Use Applications

\section{Discussion}

Online learning is essentially a learning that is able to bring students and teachers together to carry out learning interactions with the help of the internet (Kuntarto, 2017). Based on this opinion it can be said that online learning can overcome the limitations of space and time. Online learning is also able to foster independence. 
learning in students (Sadikin \& Hamidah, 2020). In another opinion it is said that the use of online applications can increase learning independence (Oknisih \& Suyoto, 2019).

The use of online learning using zoom meetings has the advantage of being able to interact directly between students and teachers as well as teaching materials (Naserly, 2020). However, all these advantages are meaningless if the teacher as a leader in online learning is unable to master technology. This fact is answered by the results of research which show that the ability of teachers to implement online learning is still low. Therefore, it is hoped that the government will pay more attention to teachers' mastery of technology and be able to complement online learning support facilities.

\section{E. Conclusion}

Based on the results of the study, it can be concluded that the teacher's ability to implement online learning in North Sumatra PAB primary schools is low. The low ability of teachers is caused by several factors, but in this study the biggest factor is the lack of motivation of teachers in learning technology, which causes online learning not to be carried out as expected. Therefore, the government's attention to mastery of technology for all teachers is something that needs to be improved considering that one of the biggest indicators of the times is the rapid development of technology.

\section{Bibliography}

Elfahmi, R. (2020). Upaya Peningkatan Kompetensi Guru Dalam Menerapkan Pembelajaran Daring Masa Pandemi Covid-19 di SMA Negeri 3 Seunagan. Bionatural: Jurnal Ilmiah Pendidikan Biologi, 7(2), 45-53.

Enriquez, M. A. (2014). Students' Perceptions on the Effectiveness of the Use of Edmodo as a Supplementary Tool for Learning. DLSU Research Congress.

Iftakhar, S. (2016). Google Classroom: What Works and How? The Journal of Education and Social Science, 3(1), 12-18.

Joshi, A., Vinay, M., \& Bhaskar, P. (2020). Impact of Coronavirus Pandemic on the Indian Education Sector: Perspectives of Teachers on Online Teaching and Assessments. Interactive Technology and Smart Education.

Kuntarto, E. (2017). Keefektifan Model Pembelajaran Daring dalam Perkuliahan Bahasa Indonesia di Perguruan Tinggi. Indonesian Language Education and Literature, 3(1), 99-110. 
Analysis of Teacher Abilitiesin Emplementing Online Learning...

Lindawati, Y. I., \& Rahman, C. A. (2020). Adaptasi Guru Dalam Implementasi Pembelajaran Daring di Era Pandemi Covid-19. Prosiding Seminar Nasional Pendidikan FKIP UNTIRTA, 3(1), 60-67.

Malyana, A. (2020). Pelaksanaan Pembelajaran Daring dan Luring Dengan Metode Bimbingan Berkelanjutan Pada Guru Sekolah Dasar di Teluk Betung Utara Bandar Lampung. Pedagogia: Jurnal Ilmiah Pendidikan Dasar indonesia, 2(1), 67-76.

Naserly, M. K. (2020). Implementasi Zoom, Google Classroom, dan Whatsapp Group dalam Mendukung Pembelajaran Daring (Online) pada Mata Kuliah Bahasa Inggris Lanjut (Studi Kasus Pada 2 Kelas Semester 2, Jurusan Administrasi Bisnis, Fakultas Ekonomi dan Bisnis, Universitas Bina Sa. Aksara Public, 4(2), 155-165.

Oknisih, N., \& Suyoto, S. (2019). Penggunaan Aplen (Aplikasi Online) Sebagai Upaya Kemandirian Belajar Siswa. Seminar Nasional Pendidikan Dasar, 1(1), 477-483.

Sadikin, A., \& Hamidah, A. (2020). Pembelajaran Daring di Tengah Wabah Covid-19. Biodik: Jurnal Ilmiah Pendidikan Biologi, 6(2), 214-224.

Sicat, A. S. (2015). Enhancing College Students' Proficiency in Business Writing Via Schoology. International Journal of Education and Research, 3(1), 159-178.

Sohrabi, C., Alsafi, Z., O'Neill, N., Khan, M., Kerwan, A., Al-Jabir, A., . . Agha, R. (2020). Corrigendum to "World Health Organization declares Global Emergency: A review of the 2019 Novel Coronavirus (COVID-19)". International Journal of Surgery, 76, 71-76.

Yusrizal, Hajar, I., \& Tanjung, S. (2019). Analysis of Elementary School Teachers' Ability in Using ICT Media and Its Impact on the Interest to Learn of Students in Banda Aceh. BirLe-Journal, 2(3), 45-57.

Yusrizal, Lubis, B. S., Fatmawati, \& Muzdalifah, D. (2020). Pengaruh Metode Visit Home dan Pola Bimbingan Orang Tua Terhadap Motivasi Belajar Siswa Sekolah Dasar di Era Pandemi Covid-19. Jurnal Tematik, 10(3), 129-135. 